\title{
Plant Growth Promotion Rhizobacteria in Onion Production
}

\author{
JOSIP ČOLO ${ }^{1}$, TIMEA I. HAJNAL-JAFARI ${ }^{2 *}$, SIMONIDA ĐURIĆ ${ }^{2}$ \\ DRAGANA STAMENOV ${ }^{2}$ and SAUD HAMIDOVIĆ ${ }^{1}$ \\ ${ }^{1}$ Faculty of Agricultural and Food Sciencies, Bosnia and Herzegowina \\ ${ }^{2}$ Faculty of Agriculture, University of Novi Sad, Novi Sad, Serbia
}

Submitted 18 June 13, revised 14 September 2013, accepted 16 November 2013

\begin{abstract}
The aim of the research was to examine the effect of rhizospheric bacteria Azotobacter chroococcum, Pseudomonas fluorescens (strains 1 and 2) and Bacillus subtilis on the growth and yield of onion and on the microorganisms in the rhizosphere of onion. The ability of microorganisms to produce indole-acetic acid (IAA), siderophores and to solubilize tricalcium phosphate (TCP) was also assessed. The experiment was conducted in field conditions, in chernozem type of soil. Bacillus subtilis was the best producer of IAA, whereas Pseudomonas fluorescens strains were better at producing siderophores and solubilizing phosphates. The longest seedling was observed with the application of Azotobacter chroococcum. The height of the plants sixty days after sowing was greater in all the inoculated variants than in the control. The highest onion yield was observed in Bacillus subtilis and Azotobacter chroococcum variants. The total number of bacteria and the number of Azotobacter chroococcum were larger in all the inoculated variants then in the control. The number of fungi decreased in most of the inoculated variants, whereas the number of actinomycetes decreased or remained the same.
\end{abstract}

Ke y w ord s: growth and yield of onion, PGP rhizobacteria, rhizospheric microorganisms

\section{Introduction}

Plant growth promoting rhizobacteria (PGPR) affect plant growth directly or indirectly by producing growth substances such as indole-acetic acid, gibberelic acid and cytokinins (Verma et al., 2010; Garcia de Salamone et al., 2001), fixing dinitrogen from the atmosphere and providing the plant with this element (Boddey and Dobereiner, 1995) and by being antagonistic towards phytopathogenic microorganisms (Velivelli et al., 2012). In recent decades, different PGPR have been studied, including nitrogen-fixing bacteria from Azotobacter genus and bacteria which produce growth substances and act as antagonists, such as Bacillus and Pseudomonas (McSpadden-Gardener, 2004; Benizri et al., 1998). The interaction between rhizobacteria and plants is not always stable in nature, thus positive results obtained in controlled conditions cannot always be replicated in field conditions (Jarak et al., 2012). The effect of PGPR varies as a result of environmental factors, which may affect both the growth of bacteria and the plant. The effect of the introduced bacteria also depends on plant physiology and agronomic conditions of cultivation. In order to achieve an optimum interaction between rhizobacteria and the plant root, it is necessary to examine the way in which rhizobacteria affect the plant and microorganisms in soil and whether this influence changes due to environmental factors, including the presence of other microorganisms, as well (Stamenov et al., 2012a).

Onion (Allium cepa) is an important vegetable plant. Due to its high adaptability, there are numerous populations and varieties of onion grown under various environmental conditions. Onion contains a large amount of carbohydrates and a small amount of proteins and fats. The biological value of onion lies in its mineral substances and vitamins. Apart from a significant amount of mineral salts, especially potassium and sulphur salts, and different oligoelements, onion abounds in vitamins (B1, B2, C, E, K), carotene (provitamin A), glycosides, etheric oils, plant hormones similar to insulin, as well as bacteriostatics (Slimestad et al., 2007). The root system of onion has low absorbing and penetrating abilities, therefore it requires an ample amount of easily accessible nutrients in the root zone. The amount of easily accessible nutrients which is necessary for optimum yield is $60-140 \mathrm{~kg} \mathrm{~N}, 60-120 \mathrm{~kg} \mathrm{P}_{2} \mathrm{O}_{5}$ and $60-180 \mathrm{~kg} \mathrm{~K} \mathrm{O}_{2}$ per hectare (Kumar, 2001). Recently,

\footnotetext{
* Corresponding author: T.I. Hajnal-Jafari, Department of Microbiology, Faculty of Agriculture, Dositeja Obradovica Sq. No. 8; phone: +381 214853 425; e-mail: mikrobiologija@polj.uns.ac.rs
} 
plant growth promoting rhizobacteria (PGPR) have come into focus as bacteria which can provide a part of necessary nutrients.

The aim of the study was to examine the effect of PGPR Bacillus subtilis, Pseudomonas fluorescens and Azotobacter chroococcum on germination, growth and yield of onion, as well as on the microbiological activity in the rhizosphere during the vegetation period of onion.

\section{Experimental}

\section{Material and Methods}

Bacterial strains. The bacteria used in the study included Azotobacter chroococcum, Pseudomonas fluorescens strain 1, Pseudomonas fluorescens strain 2 and Bacillus subtilis (from Department of Microbiology, Faculty of Agriculture, Novi Sad, Serbia). The microorganisms were propagated in appropriate nutrient media (Handbook of Microbiological Culture Media, 2000): Azotobacter chroococum in nitrogen-free medium with mannitol, Pseudomonas fluorescens in King B medium (Himedia, India), and Bacillus subtilis in nutrient agar (NA) (Torlak, Serbia).

Indole-acetic acid (IAA) production. IAA production was examined using Gordon and Weber method (Gordon and Weber, 1951). Using Salkowski reagent $\left(1 \mathrm{ml} 0.5 \mathrm{M} \mathrm{FeCl}_{3}\right.$ in $50 \mathrm{ml} 35 \% \mathrm{HClO}_{4}$ ) the production of IAA in a medium containing 0,200 and $500 \mu \mathrm{g} / \mathrm{ml}$ of L-tryptophane was determined. The volumes of $100 \mu \mathrm{l}$ of $24 \mathrm{~h}$ bacterial culture (standardized to $\mathrm{OD}_{600}$ of 0.625), were introduced into $100 \mathrm{ml}$ of liquid media: Pseudomonas into King B medium, Bacillus into NA medium and Azotobacter into nitrogen-free medium with mannitol. After $24 \mathrm{~h}$ and $48 \mathrm{~h}$, incubation at $28^{\circ} \mathrm{C}$, $5 \mathrm{ml}$ of the suspension was centrifuged at $1,957 \times \mathrm{g}$ for 15 minutes. An amount of $2 \mathrm{ml}$ of Salkowski reagent was added into $1 \mathrm{ml}$ of supernatant. Twenty-five minutes later, the intensity of the development of pink colour was measured at $530 \mathrm{~nm}$.

Phosphate solubilization. The ability of isolates to solubilize tricalcium phosphate (TCP) $\left(\mathrm{CaCO}_{3}\left(\mathrm{PO}_{4}\right)_{2}\right)$ was investigated in a Pikovskaya medium (amount $\mathrm{g}$ $\mathrm{l}^{-1}: \mathrm{KCl} 0.2 \mathrm{~g}, \mathrm{MgSO}_{4} \times 7 \mathrm{H}_{2} \mathrm{O} 0.1 \mathrm{~g}$, glucose $10 \mathrm{~g}$, yeast extract $0.5 \mathrm{~g}, \mathrm{FeSO}_{4} \times 7 \mathrm{H}_{2} \mathrm{O} 0.002 \mathrm{~g}, \mathrm{MnSO}_{4} \times \mathrm{H}_{2} \mathrm{O}$ $\left.0.002 \mathrm{~g},\left(\mathrm{NH}_{4}\right)_{2} \mathrm{SO}_{4} 0.5 \mathrm{~g}, \mathrm{Ca}_{3}\left(\mathrm{PO}_{4}\right)_{2} 5 \mathrm{~g}\right)$. An amount of $1 \mathrm{ml}$ bacterial culture, respectively (standardized to $\mathrm{OD}_{600}$ of 0.625 ) was introduced into the cooled medium, poured into a Petri dish and carefully mixed. After five days of incubation at the temperature of $28^{\circ} \mathrm{C}$, transparent zones around the colonies were measured.

Siderophore production. The ability of siderophore production was determined by the method of Milagres et al. (1999), using chrome azurol agar (CAS agar). Appropriate nutrient media for Bacillus, Pseudomonas and Azotobacter were poured into Petri dishes. After they had solidified, the media were cut into halves and one half was removed. CAS agar was poured into the empty halves of the Petri dishes. The bacteria were introduced into the halves with the nutrient medium. The incubation lasted five days at the temperature of $28^{\circ} \mathrm{C}$. In those strains which produce siderophores, the blue-green colour of CAS agar turned into orange along the demarcation line between the two media.

Field experiment. The experiment was conducted in Backi Brestovac (Vojvodina, Serbia), in carbonate chernozem soil. The soil was characterized by the following properties: $\mathrm{pH}$ in $\mathrm{H}_{2} \mathrm{O}: 8.06, \mathrm{pH}$ in $\mathrm{KCl}: 7.19$, \% $\mathrm{CaCO}_{3}: 4.62$, \% humus: $2.63, \% \mathrm{~N}: 0.13, \mathrm{mg} \mathrm{P}_{2} \mathrm{O}_{5} / 100 \mathrm{~g}$ soil: 22.27 , $\mathrm{mg} \mathrm{K}_{2} \mathrm{O} / 100 \mathrm{~g}$ soil: 18.12 . The experimental design was a randomized, complete block with four replications. The size of the experimental plots was $10 \mathrm{~m}^{2}$ (10 $\mathrm{m}$ long, $1 \mathrm{~m}$ wide). The sowing was performed on 12 March, 2012. The spacing in a row was $5 \mathrm{~cm}$ and $25 \mathrm{~cm}$ between the rows.

Bacterial treatments. The onion seed (Damascus f1 hybrid, Holland) was inoculated with four bacterial strains: 1. Azotobacter chroococcum; 2. Bacillus subtilis; 3. Pseudomonas fluorescens, strain $1 ; 4$. Pseudomonas fluorescens, strain 2; and with a mixture of strains Azotobacter chroococcum + Bacillus subtilis + Pseudomonas fluorescens, strain 1+Pseudomonas fluorescens, strain 2 (ratio $1: 1: 1: 1)$. The control was not inoculated. An amount of $50 \mathrm{ml}$ of the inoculum having the density of $10^{8} / \mathrm{ml}$ was introduced into $200 \mathrm{~g}$ of sterile peat. The inoculated peat was applied into rows, directly to the onion seed. Standard agrotechnical practices were applied during the vegetation period.

The effect of inoculation on onion growth. The germ growth was observed five and ten days after the inoculation. The onion seeds were washed with sterile tap water and placed on plastic trays with a moist filter paper. The trays were covered and placed to the incubator at $28^{\circ} \mathrm{C}$. After 48 hours the shoots of equal length were selected. The onion roots were dipped into a bacterial suspension $\left(10^{8} \mathrm{CFU} / \mathrm{ml}\right)$ for 1.5 hours. In the control the roots were moistened in sterile water. Then the onion seedlings were placed on the tray with a moist filter paper, covered and incubated at $28^{\circ} \mathrm{C}$. After five and ten days the length of the roots and the shoots was measured.

The plant height and the dry mass were measured three months after the sowing (the phase of 5-6 leaves). The bulb size and the bulb weight were measured three months after the sowing and at the end of the vegetation period (early August). The onion yield ( $\mathrm{t} / \mathrm{ha}$ ) was determined at the end of the vegetation period. 
The effect of inoculation on the microbial population in the rhizosphere of onion. The rhizospheric soil was sampled for the purpose of microbial analysis 30, 90 and 150 days after sowing. The number of microorganisms was determined by the method of agar plates in the appropriate nutrient medium: The total microbial count was performed in soil agar, (dilution $10^{-6}$ ), the fungi in potato-dextrose agar (Hy media) (dilution $10^{-4}$ ), the number of actinomycetes in Krasiljnikov agar (Hy media) (dilution $10^{-5}$ ), the total number of bacteria in nutrient agar (NA) (Torlak, Belgrade) (dilution $10^{-6}$ ) and the number of azotobacter in Fiodorov medium (Hy media) (dilution $10^{-2}$ ). All microbial analyses were performed in three replications and the average number for all three samplings was calculated per $1.0 \mathrm{~g}$ of absolutely dry soil.

Data analysis. Statistical analysis was performed by using the statistical software STATISTICA, version 12.0 (Hamburg, Germany). The significance of each treatment was established by one way ANOVA and the means were separated by Fisher's test $(\mathrm{P} \leq 0.05)$.

\section{Results and Discussion}

Indole-acetic acid (IAA) production. Indole-acetic acid (IAA) is the main auxin in plants, controlling many important physiological processes including cell enlargement and division, tissue differentiation, and responses to light and gravity. Diverse bacterial species (Bacillus spp, Streptomyces sp., Rhizobium sp., Azotobacter, Pseudomonas) possess the ability to produce IAA (Ahmad et al., 2005). According to Loper and Schorth (1986), 80\% of bacteria isolated from the rhizosphere are capable of producing IAA. In our research, all the strains were producing IAA. The best production was observed after 48 hours of incubation in the presence of $500 \mu \mathrm{g} / \mathrm{ml}$ of L-tryptophan (Table I). The best producer of IAA was Bacillus subtilis.

Phosphate solubilization and siderophore production. Phosphorus is found in soil in its organic and inorganic compounds. PGPR play a role in transforming inaccessible compounds (both organic and inorganic) into forms accessible to plants. Bacterial strains belonging to the genera Pseudomonas, Bacillus, Rhizobium, Azotobacter, Achromobacter, Agrobacterium, Micrococcus, Aerobacter, Flavobacterium and Erwinia are capable of solubilizing insoluble phosphate compounds such as tricalcium phosphate and dicalcium phosphate (Rodriguez and Fraga, 1999). Our research has shown that both Pseudomonas fluorescens strains are better TCP solubilizers than Bacillus and Azotobacter (Table II). Ravindra Naik et al., (2008) tested 443 strains of Pseudomonas. Their research showed that 80 strains (18\%) produced phosphate solubilization on Pikovskaya's agar medium by inducing clear zones. Fluorescent pseudomonad strains have also been reported as phosphate solubilizers due to the excretion of organic acids by many other researchers (Bano and Musarrat, 2004; Cattelan et al., 1999; Pandey and Palani, 1998).

Siderophores are high-affinity $\mathrm{Fe}^{3+}$ chelating compounds. In cases when accessible iron is lacking, plants and microorganisms produce siderophores which take $\mathrm{Fe}^{3+}$ out of its componds, bind it and form a Fe ${ }^{3+}$ siderophore complex. This complex is transported to the surface of a bacterial cell or root cells, transported into the cell and reduced to $\mathrm{Fe}^{2}$. Plants are capable of binding the bacterial $\mathrm{Fe}^{3+}$ siderophore complex, thus PGPR help in providing the plant with iron (Kalinowski et al., 2000). It has been proved that a large number of rhizospheric microorganisms, including Bacillus subtilis, Pseudomonas sp. and Azotobacter sp., produce siderophores (Jankiewicz, 2006, Jarak et al., 2012). In this research, Pseudomonas fluorescens strains were better siderophore producers (Table II). This is in accordance to investigation of Djurić et al. (2011). In their work, three siderophore-producing isolates of Pseudomonas fluorescens were detected. Parani and Saha (2012) also proved the existence of three siderophore producing Pseudomonas strains.

Onion growth. As PGPR produce plant hormones, the use of these bacteria usually enhances germination and early plant growth. In this research, the seed inoculation affected onion germination and growth

Table I

Indole-acetic acid (IAA) production $(\mu \mathrm{g} \mathrm{IAA} / \mathrm{ml})$

\begin{tabular}{|l|c|c|c|c|c|c|}
\hline \multirow{2}{*}{\multicolumn{1}{|c|}{ Microorganisms }} & \multicolumn{3}{|c|}{$\begin{array}{c}\text { after } 24 \mathrm{~h} \\
\text { L-tryptophan } \mu \mathrm{g} / \mathrm{ml}\end{array}$} & \multicolumn{3}{c|}{$\begin{array}{c}\text { after } 48 \mathrm{~h} \\
\text { L-tryptophan } \mu \mathrm{g} / \mathrm{ml}\end{array}$} \\
\cline { 2 - 7 } & 0 & 200 & 500 & 0 & 200 & 500 \\
\hline Pseudomonas fluorescens 1 & 2.42 & 5.39 & 7.07 & 5.32 & 12.82 & 12.93 \\
\hline Pseudomonas fluorescens 2 & 1.93 & 3.18 & 3.25 & 7.06 & 7.68 & 11.00 \\
\hline Bacillus subtilis & 12.07 & 19.75 & 20.53 & 16.93 & 26.89 & 31.71 \\
\hline Azotobacter chroococcum & 3.73 & 6.23 & 8.28 & 5.56 & 9.32 & 10.4 \\
\hline
\end{tabular}

The datas are mean values of three repetitions. 
Table II

Phosphate solubilization and siderophore production

\begin{tabular}{|l|c|c|}
\hline \multicolumn{1}{|c|}{ Microorganisms } & $\begin{array}{c}\text { Phosphate } \\
\text { solubilization } \\
\text { (halo zones- } \\
\mathrm{mm} / 5 \text { day) }\end{array}$ & $\begin{array}{c}\text { Siderophore } \\
\text { production } \\
\text { (halo zones- } \\
\mathrm{mm} / 5 \text { day) }\end{array}$ \\
\hline Pseudomonas fluorescens 1 & 7.34 & 6.70 \\
\hline Pseudomonas fluorescens 2 & 9.55 & 7.50 \\
\hline Bacillus subtilis & 5.65 & 5.20 \\
\hline Azotobacter chroococcum & 4.50 & 3.50 \\
\hline
\end{tabular}

The datas are mean values of three repetitions.

Table III

The effect of PGPR on the germ length of onion

\begin{tabular}{|l|c|c|}
\hline \multirow{2}{*}{\multicolumn{1}{|c|}{ Treatment }} & \multicolumn{2}{c|}{ Germ length $(\mathrm{mm})$} \\
\cline { 2 - 3 } & 5 days & 10 days \\
\hline Azotobacter chroococcum & 8.90 & 11.80 \\
\hline Bacillus subtilis & 8.40 & 8.90 \\
\hline Pseudomonas fluorescens 1 & 6.00 & 10.20 \\
\hline Pseudomonas fluorescens 2 & 6.20 & 9.60 \\
\hline Mixture & 6.90 & 8.40 \\
\hline Control & 4.90 & 9.10 \\
\hline LSD 0.05 & 1.22 & 1.25 \\
\hline
\end{tabular}

The datas are mean values of ten repetitions.

Table IV

The effect of PGPR on the onion growth sixty days after inoculation

\begin{tabular}{|l|c|c|c|}
\hline \multicolumn{1}{|c|}{ Treatment } & $\begin{array}{c}\text { Length of } \\
\text { the above } \\
\text { ground } \\
\text { part (cm) }\end{array}$ & $\begin{array}{c}\text { Mass of } \\
\text { the above } \\
\text { ground } \\
\text { part (g) }\end{array}$ & $\begin{array}{c}\text { Bulb } \\
\text { mass } \\
(\mathrm{g})\end{array}$ \\
\hline 1. Azotobacter chroococcum & 44.00 & 29.00 & 2.26 \\
\hline 2. Bacillus subtilis & 46.00 & 27.56 & 1.86 \\
\hline 3. Pseudomonas fluorescens 1 & 44.66 & 20.96 & 2.20 \\
\hline 4. Pseudomonas fluorescens 2 & 45.16 & 15.00 & 2.36 \\
\hline 5. Mixture & 35.96 & 30.56 & 1.16 \\
\hline 6.Control & 32.80 & 24.80 & 2.20 \\
\hline LSD 0.05 & 6.51 & 12.95 & 1.18 \\
\hline
\end{tabular}

The datas are mean values of ten repetitions.

(Table III, Table IV). Five days after the inoculation, the seedling was longer in all the inoculated variants than in the control, whereas ten days after the inoculation, the stimulating effect was visible in the variants with Azotobacter chroococcum and Pseudomonas fluorescens strains. Sixty days after the inoculation the length of the part above the ground was greater in all the inoculated variants than in the control. The fresh mass of the part above the ground was smaller in the variants inocu-
Table V

The effect of PGPR on the bulb size and onion yield

\begin{tabular}{|l|c|c|c|}
\hline \multicolumn{1}{|c|}{ Treatment } & $\begin{array}{c}\text { Bulb } \\
\text { diameter } \\
(\mathrm{cm})\end{array}$ & $\begin{array}{c}\text { Bulb } \\
\text { mass } \\
(\mathrm{g})\end{array}$ & $\begin{array}{c}\text { Yield } \\
(\mathrm{t} / \mathrm{ha})^{*}\end{array}$ \\
\hline Azotobacter chroococcum & 7.33 & 173.66 & 34.73 \\
\hline Bacillus subtilis & 7.00 & 144.00 & 28.80 \\
\hline Pseudomonas fluorescens 1 & 7.66 & 111.33 & 22.26 \\
\hline Pseudomonas fluorescens 2 & 6.80 & 121.66 & 24.33 \\
\hline Mixture & 7.33 & 130.00 & 26.00 \\
\hline Control & 6.33 & 88.00 & 17.60 \\
\hline LSD 0.05 & 1.40 & 35.52 & 7.10 \\
\hline
\end{tabular}

The datas are mean values of ten repetitions.

* calculated value

lated with Pseudomonas fluorescens strains, whereas the fresh mass of the bulb was greater in all the inoculated variants (apart from the variant with the mixture of strains). However, the increase was not statistically significant. This could be explained by the high variability of the data within treatments. The effect of the treatments was not strong enough to produce a statistically significant result.

Similar results were shown by Jarak et al. (2006) who reported a better germ development and early growth of alfalfa and red clover with the use of azotobacter, rhizobia and actinomycetes. Similarly, Stamenov et al. (2012b) reported that PGPR enhance the growth of English ryegrass. Joo et al. (2005) inoculated the pepper seed with Penibacillus polymyxa and Bacillus subtilis. In all the inoculated variants, the length and the mass of the above ground part and root significantly increased.

Onion yield. At the end of the vegetation period, onion bulbs were taken out and their size and yield were measured (Table V). The bulb diameter was larger in all the inoculated variants but the increase was of no statistical significance. The bulb weight and the yield significantly increased in the variants with Azotobacter chroococcum, Bacillus subtilis and the mixture of the inoculants. Both Azotobacter chroococcum and Bacillus subtilis take part in other important processes apart from promoting plant growth. Azotobacter can fix $60-80 \mathrm{~kg} \mathrm{~N} / \mathrm{ha}$ and thus partly provide the plant with this element (Yanni and El-Fattah, 1999, Kennedy et al., 2004), whereas Bacillus subtilis is a bioagent against phytopathogenic fungi (Kloepper et al., 2004). These properties certainly promote plant growth and increase onion yield. The use of azotobacter results in an increased yield of other plant species, too. Kumar et al. (2001), and Hajnal Jafari et al. (2012) reported that the use of azotobacter led to an increased yield of wheat and maize. The research conducted in field experiments by Mrkovacki et al. (2012) showed that inoculation of sugar beet with Azotobacter chroococcum resulted in an 
Table VI

The effect of PGPR on the number of microorganisms in the onion rhizosphere

\begin{tabular}{|l|r|r|r|r|r|}
\hline \multicolumn{1}{|c|}{ Treatment } & $\mathrm{TN} 10^{6} \mathrm{~g}^{-1}$ & $\mathrm{~TB} 10^{6} \mathrm{~g}^{-1}$ & $\mathrm{AC} 10^{5} \mathrm{~g}^{-1}$ & $\mathrm{~F} 10^{4} \mathrm{~g}^{-1}$ & $\mathrm{AZ} 10^{2} \mathrm{~g}^{-1}$ \\
\hline Azotobacter chroococcum & 329.00 & 249.90 & 11.94 & 3.05 & 168.01 \\
\hline Bacillus subtilis & 1069.90 & 1227.28 & 26.05 & 24.72 & 153.05 \\
\hline Pseudomonas fluorescens 1 & 63.94 & 1039.75 & 11.51 & 4.80 & 106.06 \\
\hline Pseudomonas fluorescens 2 & 439.82 & 995.24 & 29.92 & 10.33 & 115.34 \\
\hline Mixture & 663.66 & 1029.96 & 24.99 & 3.61 & 109.50 \\
\hline Control & 165.40 & 95.57 & 23.79 & 14.34 & 70.20 \\
\hline LSD 0.05 & 196.55 & 215.80 & 6.08 & 3.50 & 29.42 \\
\hline
\end{tabular}

The datas are mean values of three repetitions.

$\mathrm{TN}$ - total number of microorganismas; $\mathrm{TB}$ - total number of bacteria;

AC-number of actinomycetes; F-number of fungi; AZ-number of azotobacter

increased root yield and amount of extractable sucrose from the sugar beet. Nieto and Frankenberger (1991) investigated the effect of Azotobacter chroococcum on the morphology and growth of maize in vitro, in a greenhouse and in the field, and concluded that the plant growth was enhanced thanks to hormone production by azotobacter.

Microbial population in onion rhizosphere. The microbial diversity in the rhizosphere depends on root exudates, soil properties, agrotechnical measures and ecological factors. In this research, the number of the investigated groups of microorganisms was large and typical of fertile soils such as chernozem (Table VI).

Plants exude various organic and inorganic substances through their roots into the rhizosphere. The larger the number of monosaccharides and easily disintegrable organic acids in the rhizosphere, the larger the number of rhizospheric microorganisms. Onion roots exude aminoacids, sugars and organic acids which influence positively the rhizosphere (Tawaraya et al., 1995) creating favorable conditions for different microorganisms. Introducing microbiological fertilizers into soil can change the number and species of the indigenous microbial population. In this research, the total number of microorganisms (apart from treatment with Pseudomonas fluorescens strain 1), the total number of bacteria and the number of azotobacter increased in all the inoculated variants (Table VI). The number of fungi decreased in most of the inoculated variants, whereas the number of actinomycetes decreased or remained the same.

In conclusion, we demonstrated that the applied microorganisms produce IAA and siderophores and solubilize TCP. Azotobacter chroococcum is also capable of fixing atmospheric nitrogen. Bacillus subtilis has an antagonistic effect on phytopathogenic fungi and Pseudomonas fluorescens produces other biologically active substances such as hydrogen cyanide ( $\mathrm{HCN})$ and gibberellins. Some Pseudomonas fluorescens strains are used as biocontrol agents because they protect plant roots from phytopathogenic fungi such as Fusarium and Pythium. The introduction of these microorganisms into the rhizosphere leads to activation of useful microbiological processes, increase in the number of bacteria and decrease in the number of fungi. These PGPR species are already being used in the production of wheat, maize, sugar beet, rice, pepper, tomato, cucumber etc. The obtained results have shown that PGPR can also be used in onion production.

\section{Acknowledgements}

This research is part of a project TD31027 financed by the Ministry of education and science, Republic of Serbia.

\section{Literature}

Ahmad F., I. Ahmad and M.S. Khan. 2005. Indole acetic acid production by the indigenous isolates of Azotobacter and fluorescent Pseudomonas in the presence and absence of tryptophan. Turk. J. Biol. 29: 29-34.

Bano N. and J. Musarrat. 2004. Characterization of a novel carbofurandegrading Pseudomonas sp. with collateral biocontrol and plant growth promoting potential. FEMS Microbiol Lett. 231: 13-17. Benizri E., A. Courtade, C. Picard and A. Gucker t. 1998. Role of maize root exudates in the production of auxins by Pseudomonas fluorescens M.3.1. Soil Biol. Biochem. 30: 1481-1484.

Boddey R.M. and J. Dobereiner. 1995. Nitrogen fixation associated with grasses and cereals: recent progress and perspectives for the future. Fert. Res. 42: 241-250.

Cattelan A.J., P.G. Hartel and F.F. Furhmann. 1999. Screening for plant growthpromoting rhizobacteria to promote early soybean growth. Soil Sci. Soc. Am. J. 63: 1670-1680.

Djurić S., A. Pavić, M. Jarak, S. Pavlović, M. Starović, R. Pivić and D. Jošić. 2011. Selection of indigenous fluorescent pseudomonad isolates from maize rhizospheric soil in Vojvodina as possible PGPR. Romanian Biotechnol. Lett. 16 (5): 6580-6590.

García de Salamone I.E., R.K. Hynes and L.M. Nelson. 2001. Cytokinin production by plant growth promoting rhizobacteria and selected mutants. Can. J. Mcrobiol. 47: 404-411.

Gordon S.A. and R.P. Weber. 1951. Colorimetric estimation of indoleacetic acid. Plant Physiol. 26: 192-197. 
Hajnal-Jafari T., D. Latković, S. Djurić, N. Mrkovački and O. Najdenovska. 2012. The use of Azotobacter in organic maize production. Research. J. Agricultural. Sci. 44(2): 28-32.

Handbook of Microbiological Culture Media (International Ed.). 2000. Scharlau Microbiology, Barcelona, Spain.

Jankiewicz U. 2006. Syntesis of siderophores by soil bacteria of the genus Pseudomonas under various culture conditions. Acta Sci. Pol. Agricultura 5: 33-44.

Jarak M., D. Đukić and J. Čolo. 2006. The effect of bacterization and liming in the production of red clover. Grassland Science in Europe 11: 291-293.

Jarak M., N. Mrkovački, D. Bjelić, D. Jošić, T. Hajnal-Jafari and D. Stamenov. 2012. Effects of plant growth promoting rhizobacteria on maize in greenhouse and field trial. African J. Microbiol. Research 6: 5683-5690.

Jarak M., S.Đurić and J. Čolo. 2007. The effect of rhizobia, Azotobacter and Actinomycetes on the early growth of alfalfa and red clover. Book of Abstracts Power of microbes in Idustry and Environment, Zadar, Croatia p. 10.

Joo G.J., Y.M. Kin, J.T. Kim, I.K. Rhee, J. Kim and I.J. Lee. 2005 Gibberellins producing rhizobacteria increase endogenous gibberellins content and promote growth of red peppers. J. Microbiol. 43: 510-515.

Kalinowski B.E., L.J. Liermann, S. Givens and S.L. Brantley. 2000. Rates of bacteria-promoted solubilization of Fe from minerals: a review of problems and approaches. Chemical Geology 169: 357-370.

Kennedy I.R., A.I.M.A. Choudhury and M.L. KecSkes. 2004. NonSymbiotic bacterial diazotrophs in crop-farming systems: can their potential or plant growth promotion be better exploited? Soil Boil. Biochem. 36: 1229-1244.

Kloepper J.W., C.M. Ryu and S. Zhang. 2004. Induced systemic resistance and promotion of plant growth by Bacillus spp. Phytopathology 94: 1259-1266.

Kumar A. 2001. Influence of nitrogen and potassium application on growth, yield and nutrient uptake by onion (Allium cepa). Indian J. Agronomy 46: 742-746.

Kumar V., R.K. Behl and N. Narula. 2001. Establishment of phosphate-solubilizing strains of Azotobacter chroococcum in the rhizosphere and their effect on wheat cultivars under green house conditions. Microbiol. Res. 156: 87-93.

Loper J.E. and M.N. Schroth. 1986. Influence of bacterial sources of indole-3-acetic acid on root elongation of sugarbeet. Phytopatho$\log y$ 76: 386-389.

McSpadden-Gardener B.B. 2004. The nature and application of biocontrol microbes: Bacillis spp. ecology of Bacillus and Paenibacillus spp. in agricultural systems. Phytopathology 94: 661-664.
Milagres A.M.F., A. Machuca and D. Napoleao. 1999. Detection of siderophore production from several fungi and bacteria by a modification of chrome azurol S (CAS) agar plate assay. J. Microbiol. Methods 37: 1-6.

Mrkovacki N., S. Mezei, L. Kovacev, D. Bjelic, M. Jarak, S. Tyr and T. Veres. 2012. Effect of Azotobacter chroococcum application on production characteristics of sugar beet and microorganisms in sugar beet rhizosphere. Listy cukrovarnicke a reparske 128: 50-55.

Nieto K.F. and W.T. Frankenberger Jr. 1991. Influence of adenine, isopentylalcohol and Azotobacter chroococcum on the vegetative growth of Zea mays. Plant Soil 135: 213-221.

Pandey A. and L.M.S. Palani. 1998. Isolation of Pseudomonas corrugata from Sikkim himalayas. World J. Microbiol. Biotechnol. 14: 411-413.

Parani K. and B.K. Saha. 2012. Prospects of using phosphate solubilizing Pseudomonas as Bio Fertlizer. European J. Biol. Sci. 4(2): 40-44.

Ravindra Naik P., R. Gurusamy, K.B. Narayanan and S. Natarajan. 2008. Assessment of genetic and functional diversity of phosphate solubilizing fluorescent pseudomonads isolated from rhizospheric soil. BMC Microbiol. 8: 230.

Rodríguez H. and R. Fraga. 1999. Phosphate solubilizing bacteria and their role in plant growth promotion. Biotechnol. Adv. 17: 319-339.

Slimestad R., T. Fossen and I.M. Vågen. 2007. Onions: a source of unique dietary flavonoids. J. Agric. Food Chem. 55 (25): 10067-10080.

Stamenov D., M. Jarak, S. Djurić, T. Hajnal-Jafari and S. Andjelković. 2012a. The effect of azotobacter and actinomycetes on the growth of english ryegrass and microbiological activity in its rhizosphere. Research J. Agricultural. Sci. 44: 93-99.

Stamenov D., M. Jarak, S. Đurić, D. Milošev and T. Hajnal-Jafari. 2012b. Plant growth promoting rhizobacteria in the production of English ryegrass. Plant Soil Environ. 58 (10): 477-480.

Tawaraya K., S. Watanabe, E. Yoshida and T. Wagatsum. 1995. Effect of onion (Allium cepa) root exudates on the hyphal growth of Gigaspora margarita. Mycorrhiza 6: 57-59.

Velivelli S., E. O'Herlihy, B. Janczura, J. Ghyselinck and P. De Vos. 2012. Efficacy of Rhizobacteria on plant growth promotion and disease suppression in vitro. Acta Horticulturae. 961: 525-532 .

Verma P., J. Yadav, K. Nath, T. Lavakush and V. Singh. 2010. Impact of Plant Growth Promoting Rhizobacteria on Crop Production. International J. Agricultural Research 5: 954-983.

Yanni Y.G. and F.K.A. El-Fattah. 1999. Towards integrated biofertilization management with free living and associative dinitrogen fixers for enhancing rice performance in the Nile delta. Symbiosis 27: $319-331$. 